\title{
New material and evaluation of the chronostratigraphic position of Daphoenictis tedfordi (Mammalia, Carnivora, Amphicyonidae), a cat-like carnivoran from the latest Eocene of northwestern Nebraska, USA
}

\author{
Grant S. Boardman and Robert M. Hunt, Jr.
}

\begin{abstract}
One of the most enigmatic amphicyonid carnivorans, the cat-like Daphoenictis tedfordi, is now known from 12 cranio-dental specimens from North America. The most recently recovered specimen, a partial right hemimandible (UNSM 27015) described herein, adds considerably to our knowledge of this taxon, and in completeness rivals the holotype of the species. Daphoenictis tedfordi is distributed from Saskatchewan to Montana, continuing to Nebraska, Colorado, and Wyoming, with nearly $50 \%$ of the specimens coming from northwest Nebraska. The chronostratigraphy and geographic locus of the Nebraska hypodigm is the focus of this report. UNSM 27015 links the fragmentary fossils of the Nebraska hypodigm to the holotype (Cypress Hills, Saskatchewan). Chronologic evidence indicates this species is restricted to the Chadronian (late Eocene) age. Recent astronomical calibration applied to late Eocene-Oligocene tuffs places the species entirely in the middle Chadronian with a single individual found in the late early Chadronian biochron.
\end{abstract}

Grant S. Boardman. Department of Physics, Astronomy and Geology, Berry College, Mount Berry, Georgia 30149, USA, gboardman@berry.edu

Robert M. Hunt, Jr. Department of Earth and Atmospheric Sciences, University of Nebraska, Lincoln, Nebraska 68588, USA, rhunt2@unl.edu

Keywords: Carnivora; Amphicyonid; late Eocene; Chadronian; geochronology; Great Plains (Nebraska)

\section{INTRODUCTION}

The rare, cat-like genus of amphicyonid carnivoran, Daphoenictis (Hunt, 1974), is currently known from 12 specimens of Chadronian (latest Eocene) age, from Saskatchewan, Montana, Wyo- ming, Colorado, and Nebraska. A single species, $D$. tedfordi, consists primarily of partial lower jaws with dentition and a few isolated teeth but also includes a partial maxilla with $\mathrm{P} 4-\mathrm{M} 1$; a maxilla fragment with P3; and a braincase with preserved auditory region. The dentition is highly derived 
toward hypercarnivory relative to other amphicyonids of the time and is so cat-like that Hough and Alf (1956) initially identified their specimen as a felid (see Appendix).

Here we describe a recently identified and unusually complete hemimandible of Daphoenictis tedfordi from the Big Cottonwood Creek Member of the Chadron Formation. At present, the Toadstool Park area in northwest Nebraska is the only known locality with multiple individuals of this small amphicyonid. The collection site for the described specimen lies within a 3 to $4 \mathrm{~km}^{2}$ area in Sioux County that has yielded $50 \%$ of the known specimens of this genus. The bio- and chronostratigraphy of this area establish the contextual relations of this rare carnivoran.

Abbreviations. AMNH, American Museum of Natural History, New York; F:AM, Frick Collection, American Museum of Natural History, New York; NMC, National Museum of Canada, Ottawa; RAM, Raymond M. Alf Museum of Paleontology, Claremont, California; UCMP, Museum of Paleontology, University of California, Berkeley; UCR, University of California, Riverside; UNSM, University of Nebraska State Museum, Lincoln; USNM, National Museum of Natural History, Smithsonian Institution, Washington, D.C.; P, upper premolar; $\mathbf{p}$, lower premolar; M, upper molar; $\mathbf{m}$, lower molar; NALMA, North American Land Mammal "Age"; I.f., local fauna.

\section{SYSTEMATIC PALEONTOLOGY}

Class MAMMALIA Linnaeus, 1758

Order CARNIVORA Bowdich, 1821

Family AMPHICYONIDAE Haeckel, 1866

Genus DAPHOENICTIS Hunt, 1974

DAPHOENICTIS TEDFORDI Hunt, 1974

(Figure 1)

Referred Specimen. UNSM 27015 (field no. 152362) (Figure 1). Partial right hemimandible with canine, root of p1, partial p2, p3-m2, root of m3.

Locality and Stratigraphic Context. Initially reported as approximately 2 miles west of Orella and 1 mile northwest of [UNSM collecting district] Sx-41, T34N, R53W, section 31, Sioux County, Nebraska [see Site of Collection], White River Group, Big Cottonwood Creek Member, Chadron Formation. Found $10 \mathrm{ft}$ above base of an algal limestone in proximity to brontothere and equid remains.

Age. Middle Chadronian NALMA, latest Eocene.
Holotype. NMC 9205, left hemimandible with p2$\mathrm{p} 4$, m2, and damaged m1, Locality 133, Chadronian deposits of the Cypress Hills, Saskatchewan, Canada (Russell, 1972, figure 13A, B; Hunt, 1974, p.1032).

Description. The partial hemimandible preserves the majority of the mandibular body, which contains the canine, roots of the $p 1$ and $m 3$, partial p2, and p3-m2, and a part of the ascending mandibular ramus. The canine is slender and recurved with a fine enamel ridge creating a cutting edge along the distal surface and a weaker ridge at the mesiolingual face. Preserved directly distal to the canine is the broken root of the $\mathrm{p} 1$, which was single-rooted. The double-rooted $\mathrm{p} 2$ is missing most of the crown, so cusp morphology cannot be described, but the general occlusal outline of this tooth matches that of other specimens described by Hunt (1974). Premolars, p3-p4, are blade-like, narrow teeth with accessory and cingulum cusps producing a leaflike appearance in both lingual and buccal views. The p3 is taller, but mesiodistally shorter than the p4, opposite of that seen in Daphoenus and Brachyrhynchocyon. The distal accessory cusp is well developed on the p3 in contrast to other early amphicyonids (Daphoenus, Daphoenodon). Though not as tall and more robust, the $\mathrm{p} 4$ is morphologically similar to the p3, each with a distal accessory cusp, and mesial and distal cingular cusplets. The lower carnassial, $\mathrm{m} 1$, is highly diagnostic of the genus. The metaconid of the $\mathrm{m} 1$ is extremely reduced and the paraconid is advanced, placed nearly directly mesial to the protoconid. There is a marked notch between paraconid and protoconid. The $\mathrm{m} 1$ trigonid is much larger than the diminutive talonid; the talonid is reduced to a single centrally placed, knob-like hypoconid. The $\mathrm{m} 2$ is about half the length of the $\mathrm{m} 1$. The $\mathrm{m} 2$ trigonid is larger than the talonid and is dominated by a rather blunt protoconid, with a highly reduced paraconid. The metaconid is absent. The talonid of the $\mathrm{m} 2$ has a single centrally placed cusp, a hypoconid, similar to the $\mathrm{m} 1$. The $\mathrm{m} 1$ hypoconid, $\mathrm{m} 2$ protoconid, and $\mathrm{m} 2$ hypoconid form a mesiodistally aligned row of low blunt cusps useful for crushing. The mesiobuccal corner of the $\mathrm{m} 2$ is protuberant, as mentioned by Hunt (1974).

Measurements of UNSM 27015 (length $x$ width in $\mathrm{mm}$ ): canine, $7.2 \times 4.8 ; \mathrm{p} 2,7.6 \times 3.0 ; \mathrm{p} 3$, $9.9 \times 4.0 ; \mathrm{p} 4,10.4 \times 4.5 ; \mathrm{m} 1,15.2 \times 7.0 ; \mathrm{m} 2,7.2 \times$ 4.8; p2-m2, length, 48.8 . 

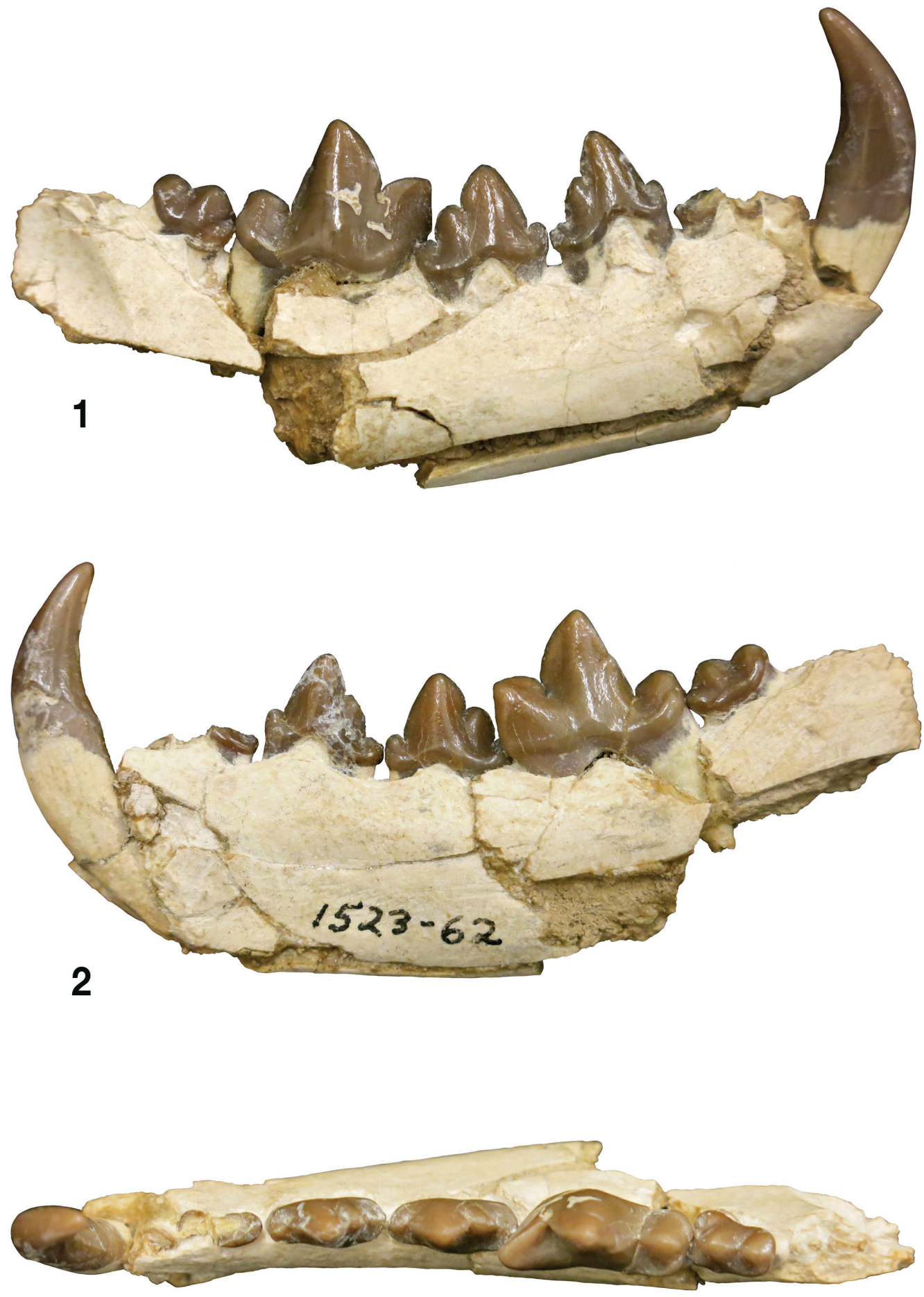

3

\section{$5 \mathrm{~cm}$}

FIGURE 1. Right hemimandible of Daphoenictis tedfordi (UNSM 27015) with canine, p3-m2, and broken base of $\mathrm{p} 2$ and single-rooted $\mathrm{p} 1$, middle Chadronian, Chadron Formation, section 31, T34N, R53W, Orella 7.5-minute topographic quadrangle, Sioux Co., Nebraska. 1, buccal view; 2, lingual view; 3, occlusal view. 


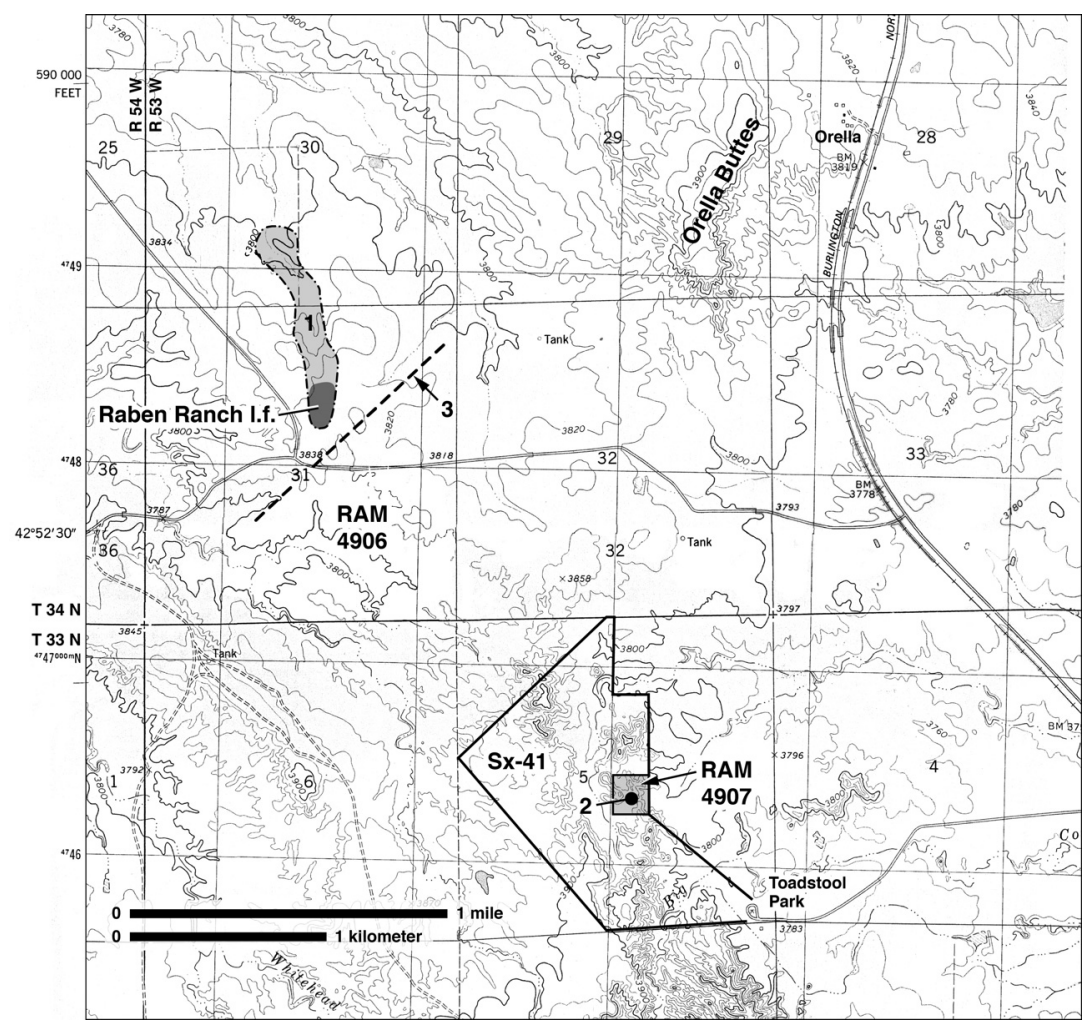

FIGURE 2. Topographic map of the Toadstool Park-Raben Ranch-Orella Buttes area, Sioux County, Nebraska. Chadron Formation outcrops here have yielded most fossils of Daphoenictis tedfordi in North America, including UNSM 27015 that closely compares with the Cypress Hills holotype, Saskatchewan. 1, ravine in sec. 31, T34N, R53W, site of the Raben Ranch local fauna and probable collecting locality of UNSM 27015; 2, stratotype of the Big Cottonwood Creek Member of the Chadron Formation (Terry and LaGarry, 1998); 3, approximate limit of the "1 mile northwest of UNSM collecting district Sx-41," stated in the UNSM locality designation for UNSM 27015 (see Site of Collection); RAM 4906 and RAM 4907, Ray Alf Museum sites where D. tedfordi was collected.

\section{RESULTS}

\section{Lithostratigraphy}

In the mid-twentieth century, investigators divided the Chadron Formation of northwest Nebraska into three sub-units (Schultz and Stout, 1955). "Chadron A" comprised the largely unfossiliferous basal conglomerate and coarse sandstones of the formation. "Chadron B" referred to the overlying, fine-textured, fossiliferous sediments capped by a prominent local chronostratigraphic marker tuff, the "Lower Purplish White" (LPW). Schultz and Stout (1955) reported the maximum thickness of Chadron B as $\sim 35 \mathrm{~m}$ (114 ft). Greenish-gray mudstones of "Chadron C" sandwiched between the LPW and the UPW ("Upper Purplish White" tuff) measured 17 to $40 \mathrm{ft}$, were moderately fossiliferous, and overlain by the Brule Formation. This nomenclature was employed by University of Nebraska field parties in the 1950s. Fossils were typically assigned to the appropriate sub-unit and, if the LPW and/or UPW were locally present, to a stratigraphic level above or below these white tuffaceous marker beds.

Remarkably, with the exception of the holotype, all known mandibular remains of Daphoenictis with intact teeth come from one locale - the Chadron Formation badlands near Toadstool Park in northwest Nebraska. We have determined that all of these fossils come from the Chadron B subunit. UNSM 27015, the new hemimandible of this report, provides the critical link between the Nebraska specimens and the holotype of $D$. tedfordi from the Cypress Hills, Saskatchewan. Here we establish the stratigraphic levels of the Toadstool Park Daphoenictis specimens, previously not precisely situated, and indicate their probable contemporaneity relative to UNSM 27015.

Two localities near the Toadstool Park campground, northwest of Crawford, Nebraska, produced the initial Daphoenictis material collected by Raymond Alf (Webb School, Claremont, California) and his students in 1950 (Figure 2). One site (RAM Locality 4907$)$ was $\sim 0.5$ mile $(0.8 \mathrm{~km})$ northwest of 
the Toadstool Park campground in the NW corner, SE1/4, sec. 5, T33N, R53W (Hough and Alf, 1956). UCMP 311018, a mandibular fragment with canine, $\mathrm{p} 2-4$, and an isolated $\mathrm{m} 1$ and $\mathrm{m} 2$, described by Hough and Alf (1956) as the felid "cf. Pseudaelurus" was collected here from Chadron B green claystones. The second site (RAM Locality 4906) was $\sim 1.5$ miles $(2.4 \mathrm{~km})$ northwest of Toadstool Park in the SE1/4, sec. 31, T34N, R53W. Richard Tedford of the American Museum of Natural History (then at the University of California, Riverside) revisited these sites with Alf in 1964, reviewing the fauna from each and sketching a defining stratigraphic section at the second locality (R.H. Tedford field notes, AMNH, July 20, 1964). Tedford learned that this second site had produced two unusual mandibular fragments, which were not recognized until 1974 as Daphoenictis (UCMP 311021,311022 ). At RAM Locality 4906 , his stratigraphic section (Figure 3) measures $26 \mathrm{~m}(85 \mathrm{ft})$ of

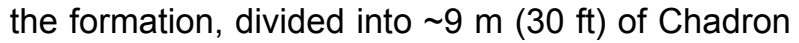

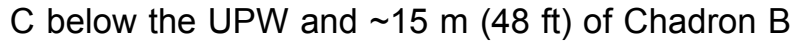
below the LPW. Tedford established that the Hough-Alf fauna here came from a $\sim 5 \mathrm{~m}(15 \mathrm{ft})$ interval of Chadron B from $\sim 10$ to $15 \mathrm{~m}$ (33 to $48 \mathrm{ft}$ ) below the LPW. Tedford and Alf determined that the mammals found in place in 1950 at RAM Locs. 4906-4907 mostly came from the B3 unit, a subdivision of Chadron $B$ occurring between the Third and Fourth Purplish White beds of Schultz and Stout (1955, figure 3, section 2), two additional local marker beds.

The lithostratigraphy of the Chadron Formation in the Toadstool Park area was revised by Terry (1998) and Terry and LaGarry (1998). These authors recognized the historic role of the Purplish White beds used as reference levels to stratigraphically assign fossils in the vicinity of Toadstool Park. They replaced Chadron $C$ and the upper part of Chadron $B$ with a more precisely defined lithologic unit, the Big Cottonwood Creek Member of the Chadron Formation. The lower part of Chadron B was assigned to the Peanut Peak Member, a bluegreen, smectite-rich mudstone (Terry, 1998). All four principal Purplish White beds were reported to occur within the Big Cottonwood Creek Member. In the Toadstool Park area, the Fourth Purplish White bed is the Chadron $\mathrm{B}^{3} / \mathrm{B}^{2}$ boundary and caps the Peanut Peak Member (Terry and LaGarry, 1998).

These authors placed the stratotype of the Big Cottonwood Creek Member (Figure 2.2) in the SE1/4, sec. 5, T33N, R53W, approximately 0.2 miles south of where Daphoenictis (UCMP 311018) had been collected. The Big Cottonwood Creek

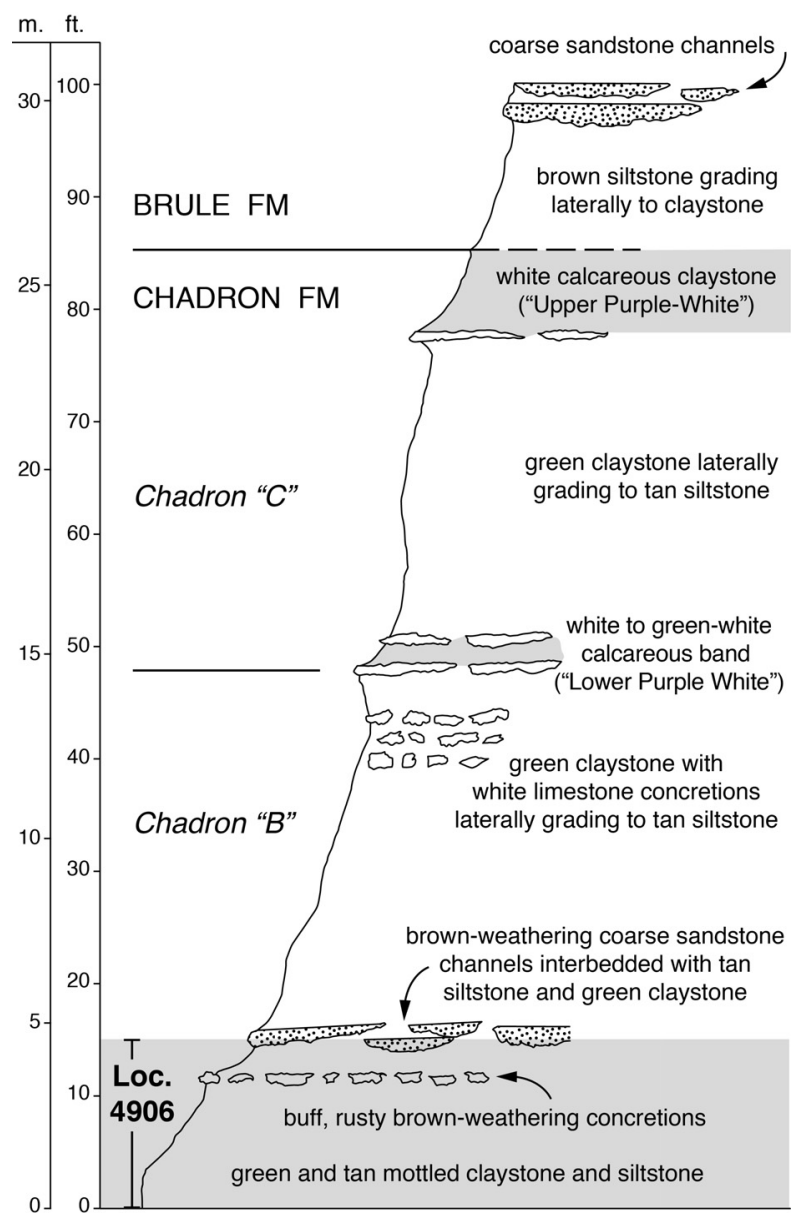

FIGURE 3. Stratigraphic section of the Chadron Formation including RAM Locality 4906, SE1/4, sec. 31, T34N, R53W, Sioux Co., Nebraska, measured by R.H. Tedford in 1964. Note the LPW (Lower Purple-White) and UPW (Upper Purple-White) ashes relative to the faunal horizon.

Member at its stratotype measures $\sim 25 \mathrm{~m}$ and the Peanut Peak Member $\sim 5 \mathrm{~m}$ for a total thickness of $\sim 30 \mathrm{~m}$ (98 ft), whereas Hough and Alf (1956) described a $\sim 24 \mathrm{~m}(80 \mathrm{ft})$ section there. Hough and Alf reported that most mammals collected in place were from an interval $9 \mathrm{~m}(\sim 30 \mathrm{ft})$ below the LPW, which places them within the Big Cottonwood Creek Member and in Chadron B of Schultz and Stout (1955), mostly in their $B^{3}$ subunit.

The Toadstool Park stratotype of the Big Cottonwood Creek Member (25 m) compares in thickness to Tedford's combined Chadron B and C (26 $\mathrm{m})$ measured in the SE1/4 of section 31 . The occurrence of Daphoenictis (UCMP 311018) 9 m below the LPW in the SE1/4, section 5, T33N, 


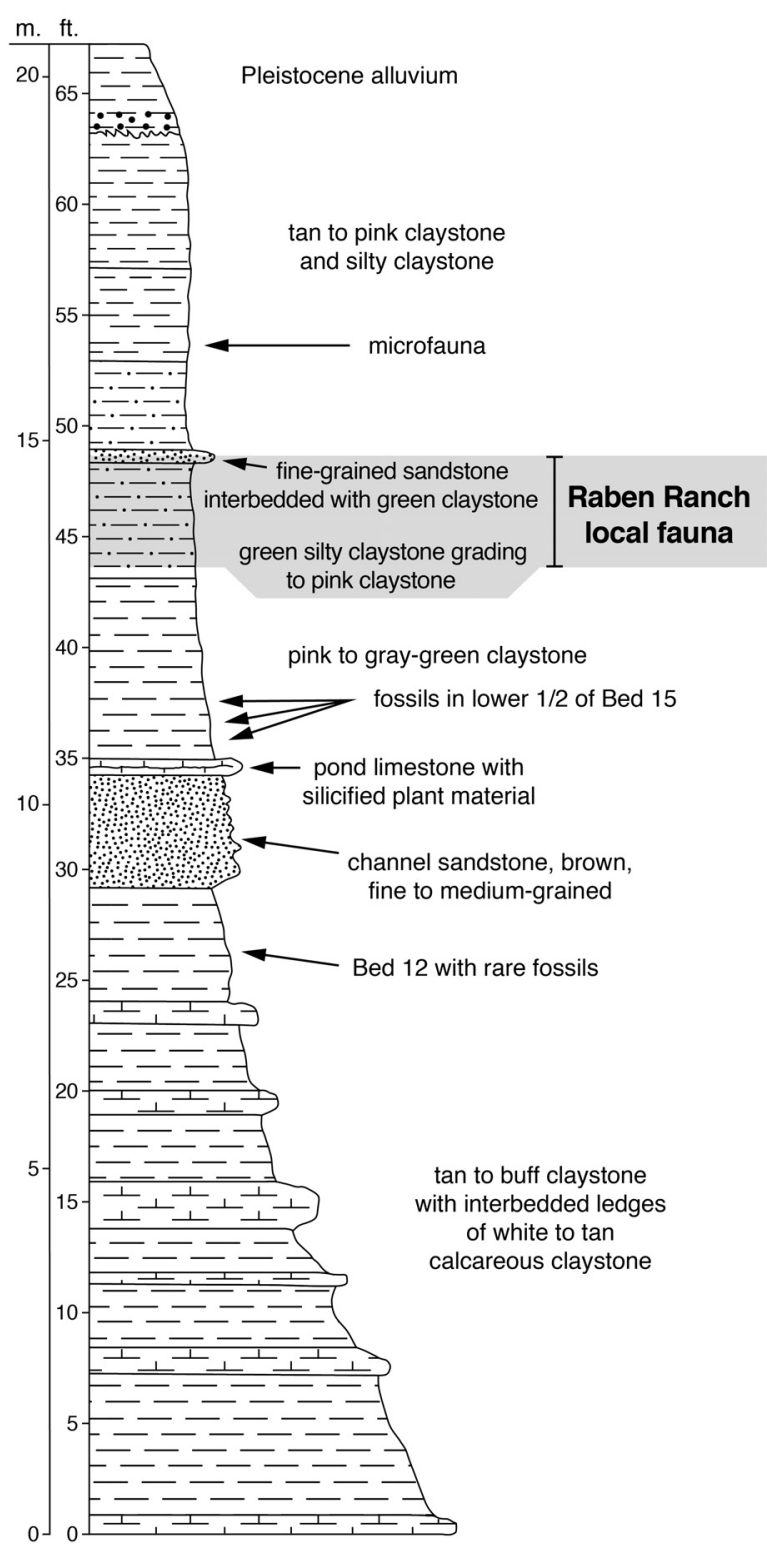

FIGURE 4. Stratigraphic section of the Chadron Formation from Ostrander (1985, fig. 5) in W1/2, NE1/4, sec. $31, T 34 N$, R53W, with the Raben Ranch local fauna and the fossiliferous interval above and below the "pond limestone" that corresponds to the stratigraphic interval that produced the UNSM assemblage with Daphoenictis.

R53W is in stratigraphic proximity to the Daphoenictis specimens (UCMP 311021, 311022) from 10 to $15 \mathrm{~m}$ below the LPW in the SE1/4 of section 31 . If the sedimentation rate is similar in the two sections, the fossils appear to share approximately the same stratigraphic level.

\section{Site of Collection of Daphoenictis (UNSM 27015)}

Records of the University of Nebraska's Division of Vertebrate Paleontology report UNSM 27015 (field no. 1523-62) was collected in 1962 from the Chadron Formation, "10 feet above the base of an algal limestone," in sec. $31, \mathrm{~T} 34 \mathrm{~N}$, R53W, 1 mile northwest of UNSM collecting district Sx-41 and 2 miles west of Orella, Nebraska. The jaw was initially identified as a hemimandible of ?Cynodictis, then thought to be a canid. UNSM field data indicate that it was found with titanothere and other fossils. However, "approximately 2 miles west of Orella and 1 mile northwest of Sx-41," are incompatible locations. If "1 mile northwest of Sx41 " is correct, then the collection site cannot be 2 miles west of Orella, which is 2 miles northwest of Sx-41 where there are few Chadron outcrops. Prominent Chadron exposures are developed $\sim 1.8$ miles southwest of Orella on the Raben Ranch (Figure 2.1), which is approximately " 1 mile northwest of Sx-41" (Figure 2.3) and would place the site of the UNSM collection at or near a ravine in the W1/2, NE1/4, sec. 31, T34N, R53W, the source of the Raben Ranch local fauna (Ostrander, 1983, 1984), a diverse and important Chadronian assemblage. Ostrander (1985, figure 5) published a measured section in which the local fauna occurred in his beds 16 and 17 with additional mammals from the lower part of bed 15 (Figure 4). Prothero (1996, figure 6 ) later published the magnetostratigraphy of this section.

Of significance is that Ostrander's (1985) Raben Ranch section includes a "pond limestone" with silicified plant material; the Raben Ranch mammals were found from $\sim 10 \mathrm{ft}(3 \mathrm{~m})$ below to $\sim 14 \mathrm{ft}(\sim 4 \mathrm{~m})$ above this "pond limestone". In 1962 the UNSM assemblage with Daphoenictis was collected from $8 \mathrm{ft}(2.4 \mathrm{~m})$ below to $15 \mathrm{ft}(4.5 \mathrm{~m})$ above an "algal limestone" over a remarkably similar stratigraphic interval. This suggests that the UNSM assemblage with Daphoenictis (UNSM 27015) was collected from the ravine yielding the Raben Ranch mammals. Terry and LaGarry (1998) placed the Raben Ranch local fauna within the lower half of their Big Cottonwood Creek Member.

We conclude that the following Nebraska localities are approximately contemporaneous and of middle Chadronian age, based on the preceding stratigraphic analysis: 1) northern locality of Hough and Alf (RAM 4906) in the SE1/4 of section 31, T34N, R53W; 2) the southern locality of Hough and Alf (RAM 4907) in proximity to Terry and LaGarry's (1998, figure 3) stratotype of the Big Cottonwood 
Creek Member northwest of Toadstool Park; and 3) the Raben Ranch locality and UNSM assemblage with Daphoenictis (UNSM 27015). These localities appear to correlate with the fauna found between Ash B and Ash $\mathrm{G}$ at Flagstaff Rim, Wyoming.

\section{DISCUSSION}

\section{Geochronology}

Ashes B, G, and $\mathrm{J}$ at Flagstaff Rim in Wyoming, and the UPW ash in Nebraska are key to calibrating the first and last occurrences of North American Daphoenictis tedfordi; Ash G at Flagstaff Rim is less confidently dated relative to Ashes $B$ and $\mathrm{J}$ but is reported to approximate the upper limit for the middle Chadronian (Prothero and Emry, 2004). The sanidine standard age (27.84 Ma) derived from the Fish Canyon Tuff used in calculating ${ }^{40} \mathrm{Ar} /{ }^{39} \mathrm{Ar}$ ages for the $\mathrm{B}$ and $\mathrm{J}$ ashes by Obradovich et al. (1995) has been recalibrated first to $28.02 \pm 0.28$ (Renne et al., 1998), then to $28.201 \pm$ 0.046 based on recent astronomical calibration of the standard (Kuiper et al., 2008). Ash B or Ash J then may each range in age over as much as $\sim 400,000$ years (Hilgen and Kuiper, 2009).

Radioisotopic dating of North American late Eocene-Oligocene tuffs through ID-TIMS U/Pb dating of zircon and SCLF ${ }^{40} \mathrm{Ar} /{ }^{39} \mathrm{Ar}$ dating of sanidine relative to astronomical calibration of the geomagnetic polarity time scale at present is a work in progress (Pälike et al., 2006; Kuiper et al., 2008; Hilgen and Kuiper, 2009; Sahy et al., 2013). A sanidine age of $35.41 \mathrm{Ma}$ was reported by Obradovich et al. (1995) for Ash B, then recalibrated to 35.64 Ma (Renne et al., 1998), and later astronomically calibrated to 35.87 Ma (Hilgen and Kuiper, 2009). Ash B constrains the upper limit of the late early Chadronian at Flagstaff Rim, with the reference

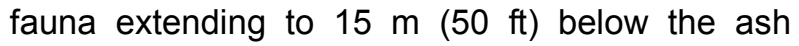
(Prothero and Emry, 2004). Ash G remains an unresolved age (Hilgen and Kuiper, 2009, figure 1), yet earlier placed in a correlation chart at $\sim 35 \mathrm{Ma}$ by Prothero and Emry (2004, figure 5.2). A sanidine age of 34.36 Ma for Ash $\mathbf{J}$ was determined by Obradovich et al. (1995), recalibrated to $34.58 \mathrm{Ma}$ (Renne et al., 1998), then astronomically recalibrated to 34.81 Ma (Hilgen and Kuiper, 2009). Significantly, Ash $\mathrm{J}$ was correlated by phenocrysts to northwest Nebraska's UPW ash by Larsen and Evanoff (1998). All of the calibrations indicate $\sim 1$ million years between deposition of Ash B and Ash J. All place this interval within the late Eocene.

\section{Biochronology}

Daphoenictis tedfordi is restricted to the Chadronian NALMA. Prothero and Emry (2004) established temporal intervals for the earliest, late early, middle, and late Chadronian. They placed the first occurrence of Daphoenictis tedfordi in the late early Chadronian (35.7-36.5 Ma), with the species continuing through the middle Chadronian (34.7$35.7 \mathrm{Ma}$ ). Zanazzi et al. (2009) recently discussed the biostratigraphy of Chadronian age deposits at Toadstool Park, employing the stratigraphic occurrence of small leptomerycid artiodactyls relative to White River Group ashes. Their boundary ages separating the early Chadronian-middle Chadronian (35.7 Ma), middle Chadronian-late Chadronian (34.8 Ma), and late Chadronian-Orellan (33.9 $\mathrm{Ma})$ are nearly identical to those of Prothero and Emry (2004). Zanazzi et al. (2009) recognized the Hilgen-Kuiper astronomic calibration that places the mid-late Chadronian boundary at $\sim 34.8$, the correlated age of the UPW ash.

First Occurrence. Dry Hole Quarry at Flagstaff Rim, Wyoming, a late early Chadronian locality, yielded the Daphoenictis tedfordi maxilla (USNM 214642) that is likely the oldest record of the species (Emry and Hunt, 1980). It was found $24 \mathrm{~m}$ (80 $\mathrm{ft}$ ) above the base of the formation at Flagstaff Rim and $28 \mathrm{~m}(90 \mathrm{ft})$ below Ash B. Considering the range of the original and recalibrated ages for Ash B (35.41 to $35.87 \mathrm{Ma}$, Hilgen and Kuiper, 2009), D. tedfordi likely falls within the late early Chadronian and could be as old as $\sim 36 \mathrm{Ma}$.

The Flagstaff Rim section below Ash B includes archaic taxa (Hemipsalodon sp., Toxotherium hunteri, Parictis parvus, Pseudoprotoceras semicinctus, Yoderimys stewarti). These are also present in the Calf Creek local fauna, Saskatchewan, the source of the Chadronian Daphoenictis tedfordi holotype. However, the maxilla of $D$. tedfordi is probably older than the Calf Creek holotype, given that the leptomerycids Leptomeryx yoderi and $L$. speciosus at Dry Hole Quarry register an earlier evolutionary stage than those ( $L$. speciosus and L. mammifer) at Calf Creek (Heaton and Emry, 1996; Storer, 1996). Overall, the fossil record at Flagstaff Rim records the splitting of an ancestral Leptomeryx yoderi (from Low Pocket Quarry) into $L$. yoderi and $L$. speciosus (Dry Hole Quarry), which evolve to $L$. speciosus and $L$. mammifer that characterize the middle Chadronian Ash B to Ash $G$ interval (Heaton and Emry, 1996).

The isolated Daphoenictis carnassial (m1) from the Pipestone Springs Main Locality, Montana, is of middle Chadronian age, correlated to 
Flagstaff Rim between Ash B and Ash G (Prothero and Emry, 2004).

Last Occurrence. The youngest occurrence of Daphoenictis tedfordi is the mandibular fragment (F:AM 25242) collected by M.F. Skinner at Brecht Ranch in northwest Nebraska from a massive pink claystone in the upper Chadron Formation. The specimen came from the same location as Gustafson's (1986) measured section \#2 (NW1/4, sec. 9 , T32N, R49W), possibly from his bed 5 , and collected $\sim 12$ feet $(3.6 \mathrm{~m})$ below the UPW. Gustafson (1986) indicated that most fossils of the Brecht Ranch local fauna are from the $3 \mathrm{~m}$ of section below this ash. He noted that Daphoenictis occurred in the fauna with Hypertragulus calcaratus and Leptomeryx evansi, these two species common in the Orellan, yet generally not considered to extend into the Chadronian. However, at Toadstool Park, $H$. calcaratus and $L$. evansi also occur 2-3 $\mathrm{m}$ below the UPW and continue into the Orella Member of the Brule Formation (Zannazi et al., 2009). Although the Chadron Formation records of $H$. calcaratus and $L$. evansi have been regarded as remanié washed down from higher stratigraphic levels, the reports of both species below the UPW at Brecht Ranch and at Toadstool Park merit consideration of their presence in the Chadronian.

Because the Brecht Ranch Daphoenictis occurs a few meters below the UPW, its age relies on the correlation established between the UPW at Toadstool and Ash $\mathrm{J}$ at Flagstaff Rim (Larsen and Evanoff, 1998). The last occurrence of $D$. tedfordi is then either near the end of the middle Chadronian or within the earlier part of the late Chadronian, given the 34.36 to 34.81 Ma recalibrated age range for Ash J (Hilgen and Kuiper, 2009, figure 1).

Thus, the age of fossils of Daphoenictis tedfordi from Nebraska and central Wyoming where the species is most common falls with confidence in the interval from $\sim 34 \mathrm{Ma}$ to $\sim 36 \mathrm{Ma}$. Taking into consideration the most recent astronomical calibration of the Fish Canyon Tuff sanidine (Hilgen and Kuiper, 2009), the earliest occurrence of Daphoenictis occurs in the late early Chadronian with the remainder of the hypodigm confined to the middle Chadronian.

\section{ACKNOWLEDGMENTS}

We thank E. Stepleton and R. Skolnick (UNSM) for preparation of UNSM 27015, and A. Fox (UNSM) for Figures1-4. D. Pagnac (South Dakota School of Mines and Technology, Rapid
City) provided information involving the Raben Ranch locality, northwest Nebraska. For review of the manuscript we thank R. Secord, D. Pagnac, B. Van Valkenburgh, M.J. Salesa, and an anonymous reviewer.

\section{REFERENCES}

Bowdich, T.E. 1821. An Analysis of the Natural Classifications of Mammalia for the Use of Students and Travellers. J. Smith, Paris.

Emry, R.J. and Hunt, R.M., Jr. 1980. Maxillary dentition and new records of Daphoenictis, an Oligocene amphicyonid carnivore. Journal of Mammalogy, 61:720-723.

Gustafson, E.P. 1986. Preliminary biostratigraphy of the White River Group (Oligocene, Chadron and Brule Formations) in the vicinity of Chadron, Nebraska. Transactions of the Nebraska Academy of Sciences, 14:7-19.

Haeckel, E. 1866. Generelle Morphologie der Organismen. Allgemeine Grundzüge der Organischen Formenwissenschaft, Mechanisch Begründet durch die von Charles Darwin Reformierte Deszendenz-Theorie. Band I: Allgemeine Anatomie der Organismen. Georg Reimer, Berlin.

Heaton, T.H. and Emry, R.J. 1996. Leptomerycidae, p. 581-608. In Prothero, D.R. and Emry, R.J. (eds.), The Terrestrial Eocene-Oligocene Transition in North America. Cambridge University Press, New York.

Hilgen, F.J. and Kuiper, K.F. 2009. A critical evaluation of the numerical age of the Eocene-Oligocene boundary. Geological Society of America Special Paper, 452:139-148.

Hough, J. and Alf, R. 1956. A Chadron mammalian fauna from Nebraska. Journal of Paleontology, 30:132-140.

Hunt, R.M., Jr. 1974. Daphoenictis, a cat-like carnivore (Mammalia, Amphicyonidae) from the Oligocene of North America. Journal of Paleontology, 48:10301047.

Kuiper, K.F., Deino, A., Hilgen, F.J., Krijgsman, W., Renne, P.R., and Wijbrans, J.R.. 2008. Synchronizing rock clocks of Earth history. Science, 320:500504.

Larson, E.E. and Evanoff, E. 1998. Tephrostratigraphy and source of tuffs of the White River sequence. Geological Society of America Special Paper, 325:114.

Linnaeus (Linné), C. 1758. Systema naturae per regna tria naturae, secundem classes, ordines, genera, species cum characteribus, differentiis, synonymis, locis. Editio decimal, reformata. Laurentii Salvii, Stockholm.

McKenna, M.C. 1972. Vertebrate Paleontology of the Togwotee Pass Area, Northwestern Wyoming, Field Conference Guidebook on Tertiary Biostratigraphy of Southern and Western Wyoming. American Museum of Natural History, New York. 
Obradovich, J.D., Evanoff, E., and Larson, E.E. 1995. Revised single-crystal laser-fusion ${ }^{40} \mathrm{Ar} /{ }^{39} \mathrm{Ar}$ ages of Chadronian tuffs in the White River Formation of Wyoming. Geological Society of America, Abstracts with Programs, 27:77-78.

Ostrander, G.E. 1983. New early Oligocene (Chadronian) mammals from the Raben Ranch local fauna, northwest Nebraska. Journal of Paleontology, 57:128-139.

Ostrander, G.E. 1984. The early Oligocene (Chadronian) Raben Ranch local fauna, northwest Nebraska: Multituberculata; with comments on the extinction of the Allotheria. Transactions of the Nebraska Academy of Sciences, 12:71-80.

Ostrander, G.E. 1985. Correlation of the early Oligocene (Chadronian) in northwest Nebraska. Dakoterra, 2:205-231.

Pälike, H., Norris, R.D., Herrle, J.O., Wilson, P.A., Coxall, H.K., Lear, C.H., Shackleton, N.J., Tripati, A.K., and Wade, B.S. 2006. The heartbeat of the Oligocene climate system. Science, 314:1894-1898.

Prothero, D.R. 1996. Magnetic stratigraphy of the White River Group in the high plains, p. 262-277. In Prothero, D.R. and Emry, R.J. (eds), The Terrestrial Eocene-Oligocene Transition in North America. Cambridge University Press, New York.

Prothero, D.R. and Emry, R.J. 2004. The Chadronian, Orellan, and Whitneyan North American land mammal ages, p. 156-168. In Woodburne, M.O. (ed.), Late Cretaceous and Cenozoic Mammals of North America: Biostratigraphy and Geochronology. Columbia University Press, New York.
Renne, P.R., Swisher, C.C., Deino, A.L., Karner, D.B., Owens, T.L., and DePaolo, D.J. 1998. Intercalibration of standards, absolute ages and uncertainties in ${ }^{40} \mathrm{Ar} /{ }^{39} \mathrm{Ar}$ dating. Chemical Geology, 145:117-152.

Russell, L. 1972. Tertiary mammals of Saskatchewan, Part II: The Oligocene fauna, non-ungulate orders. Royal Ontario Museum Life Sciences Contribution, 84:1-97.

Sahy, D., Fischer, A.U., Condon, D.J., Terry, D.O., Hiess, J., Abels, H., Huesing, S.K., and Kuiper, K.F. 2013. Radio-isotopic calibration of the Late Eocene-Early Oligocene geomagnetic polarity time scale. Geophysical Research Abstracts 15:EGU2013:10252.

Schultz, C.B. and Stout, T.M. 1955. Classification of Oligocene sediments in Nebraska. Bulletin of the University of Nebraska State Museum, 4:17-52.

Storer, J.E. 1996. Eocene-Oligocene faunas of the Cypress Hills Formation, Saskatchewan, p. 240-261. In Prothero, D.R. and Emry, R.J. (eds.), The Terrestrial Eocene-Oligocene Transition in North America. Cambridge University Press, New York.

Terry, D.O. 1998. Lithostratigraphic revision and correlation of the lower part of the White River Group: South Dakota to Nebraska. Geological Society of America Special Paper, 325:15-37.

Terry, D.O. and LaGarry, H.E. 1998. Big Cottonwood Creek Member: a new member of the Chadron Formation in northwestern Nebraska. Geological Society of America Special Paper, 325:117-141.

Zanazzi, A., Kohn, M.J., and Terry, D.O. 2009. Biostratigraphy and paleoclimatology of the Eocene-Oligocene boundary section at Toadstool Park (northwestern Nebraska). Geological Society of America Special Paper, 452:197-214. 


\section{APPENDIX}

\section{Chronologic history of the Daphoenictis hypodigm: 1937-1980}

In 1950, paleontologist Raymond Alf and students from the Webb School, Claremont, California, explored Chadron Formation badlands northwest of Toadstool Park in the NW corner, SE1/4, sec. 5, T33N, R53W, Sioux County, Nebraska (Figure 2). Among the numerous Chadronian mammals collected was a partial hemimandible with cat-like dentition (UCMP 311018, previously UCR 11018), which at that time was referred to the felid "cf. Pseudaelurus" (Hough and Alf, 1956). Also, two mandibular fragments with dentition (UCMP 311021, 311022, previously UCR $11021,11022)$, representing this same carnivoran, were collected from Chadron Formation outcrops $\sim 1$ mile northwest of the previous locality in the SE1/4, sec. 31, T34N, R53W, but these were neither identified nor described.

A few additional specimens of this enigmatic cat-like species accumulated in Chadronian collections of the Frick Laboratory (AMNH) in the 1950s but failed to attract notice. A mandibular fragment with $m 2$ and damaged $m 1$ (F:AM 25242) was found by M.F. Skinner in 1953 at Brecht Ranch, southwest of Chadron, Nebraska. In 1958, a second mandibular fragment with $\mathrm{m} 1$ trigonid and $\mathrm{m} 2-\mathrm{m} 3$ (F:AM 76205) and a posterior cranium were collected in Chadronian White River beds at Flagstaff Rim, in central Wyoming, by Skinner, T. Galusha, R. J. Emry, and C. Elfgren. The cranium and mandibular fragment, found together, were given a common field number $(\mathrm{BH} 28-650)$ and considered to belong to the same individual.

Identification of this carnivoran came about through publication of a hemimandible with p3-m2 (NMC 9205) recovered in 1937 from Chadronian deposits of the Cypress Hills, Saskatchewan (Russell, 1972). Russell assigned the jaw to the "canid" Daphoenus. Importantly, the molars of the Flagstaff
Rim jaw and the teeth of the previously unrecognized jaw fragments from Nebraska were seen to match the intact teeth in Russell's Cypress Hills jaw, and it was then discovered that the Flagstaff Rim cranium exhibited amphicyonid basicranial features (Hunt, 1974). As a result the fossils were assigned to a new genus and species, Daphoenictis tedfordi, and placed in the Amphicyonidae. The Cypress Hill jaw was designated the species holotype.

No upper teeth of this carnivoran were known until, in the early1970s, a high-altitude outlier of the White River Group in northwest Wyoming produced a Chadronian fauna (McKenna, 1972) that included a partial maxilla with a tall dagger-like P3 (AMNH 56351). This distinctive P3 was later recognized in another maxilla that preserved P3-M1 (USNM 214642) from Chadronian sediments at Flagstaff Rim. Because its upper teeth evidenced the trenchant form suggested by the lower dentition, the maxilla was referred to Daphoenictis (Emry and Hunt, 1980). These authors also included in Daphoenictis an unrecognized isolated m1 from Chadronian beds at Pipestone Springs (Main Locality), Montana, collected in 1948 (USNM 215031).

The intact hemimandible of Daphoenictis tedfordi (UNSM 27015) described in this report was discovered in 1962 near the locations in northwestern Nebraska where Raymond Alf collected the specimens in 1950 later referred to Daphoenictis. With the addition of UNSM 27015, the Chadronian badlands of the White River Group northwest of Toadstool Park become the principal geographic area yielding fossils of Daphoenictis. This district includes the Chadronian Raben Ranch local fauna preserving one of the few North American occurrences of latest Eocene multituberculates and other relict early Paleogene taxa (Ostrander, 1983, 1984, 1985). 